\title{
PERANAN OPINION LEADER DALAM KELOMPOK NELAYAN PESISIR
}

\author{
Titien Yusnita ${ }^{1)}$, Sarwiti S Agung ${ }^{2)}$, Amiruddin Saleh ${ }^{3)}$ \\ ${ }^{1)}$ Mahasiswa Program studi S3 KMP IPB \\ ${ }^{2)}$ Staf Pengajar Program Pascasarjana Prodi KMP IPB \\ ${ }^{3)}$ Staf Pengajar Program Pascasarjana Prodi KMP IPB
}

\begin{abstract}
Fishing community is a part of Indonesian people which survives by managing fishery resources. As a society living in an offshore area, fishing community has unique social characteristics which differentiates it from land community. This study aimed to see the cause of poverty and livelihood strategy of poor household as well as to design the community based-sustainable livelihood strategy. The literature study shows that prosperous coastal fishermen existed among poor coastal fishermen. They differed in social and economic condition. It happened because of the role of a coastal fishermen group which was capable of managing the fund got from government or another institutions. In this case the role of group leader as the opinion leader was very significant that established an effective communication.

Keywords : coastal fisherman group, opinion leader
\end{abstract}

\section{PENDAHULUAN}

\section{Latar Belakang}

Sebagai suatu kesatuan sosial, masyarakat nelayan hidup, tumbuh, dan berkembang di wilayah pesisir atau wilayah pantai. Dalam konstruksi sosial masyarakat di kawasan pesisir, masyarakat nelayan merupakan bagian dari konstruksi sosial tersebut meskipun disadari bahwa tidak semua desa-desa di kawasan pesisir memiliki penduduk yang bermatapencaharian sebagai nelayan. Walaupun demikian, di desadesa pesisir yang sebagian besar penduduknya bermatapencaharian sebagai nelayan, petambak, atau pembudidaya perairan. Kebudayaan nelayan berpengaruh besar terhadap terbentuknya identitas kebudayaan masyarakat pesisir secara keseluruhan (Ginkel, 2007). Baik nelayan, petambak, maupun pembudidaya perairan merupakan kelompokkelompok sosial yang langsung berhubungan dengan pengelolaan sumber daya pesisir dan kelautan.

Masyarakat nelayan merupakan salah satu bagian masyarakat Indonesia yang hidup dengan mengelola potensi sumberdaya perikanan. Sebagai masyarakat yang tinggal di kawasan pesisir, masyarakat nelayan mempunyai karakteristik sosial tersendiri yang berbeda dengan masyarakat yang tinggal di wilayah daratan. Di beberapa kawasan pesisir yang relatif berkembang pesat, struktur masyarakatnya bersifat heterogen, memiliki etos kerja yang tinggi, solidaritas sosial yang kuat terbuka terhadap perubahan, dan memiliki karakteristik interaksi sosial yang mendalam. Sekalipun demikian masalah kemiskinan masih mendera sebagian warga masyarakat pesisir sehingga fakta sosial ini terkesan ironi ditengah-tengah hasil kekayaan sumberdaya pesisir dan lautan yang melimpah ruah.

Kesulitan melepaskan diri dari belenggu kemiskinan karena didera keterbatasan di bidang kualitas sumberdaya manusia, akses dan penguasaan teknologi, serta pasar dan modal. Kebijakan dan implementasi program-program pembangunan untuk masyarakat di kawasan pesisir hingga saat ini masih belum optimal dalam memutus mata rantai kemiskinan dan meningkatkan kesejahteraan mereka. 
Hal ini disebabkan oleh porsi kebijakan pembangunan bidang sosial, ekonomi ,dan budaya pada masyarakat nelayan cukup kompleks.

Seperti diketahui kebudayaan suatu masyarakat yang faktornya sangat ditentukan oleh lingkungan fisik dan sosial budaya memberikan bentuk tentang apa dan bagaimana kehidupan yang memuaskan. Para nelayan pesisir secara turun temurun berada di lingkungan pesisir dengan kehidupan sosial budaya yang khas. Kekayaan alam yang terkandung dalam laut serta program-program bantuan pemerintah belum mengubah kehidupan nelayan yang didera kemiskinan. Oleh sebab itu, makalah ini bertujuan untuk mencari celah solusi bagaimana pengentasan kemiskinan pada masyarakat nelayan pesisir dengan membandingkan penelitian-penelitian terdahulu.

\section{Penelitian Terdahulu}

Sebagai sebuah entitas sosial, masyarakat nelayan memiliki sistem budaya yang tersendiri dan berbeda dengan masyarakat lain yang hidup di daerah pegunungan, lembah atau dataran rendah maupun perkotaan dimana terdapat beberapa aspek antropologis yang dipandang penting sebagai pembangun identitas kebudayaan masyarakat nelayan, seperti sistem gender, relasi patron-klien, polapola eksploitasi sumber daya perikanan, dan kepemimpinan sosial (Kusnadi, 2004). Kemiskinan nelayan pesisir (Fargomeli, 2004) bahwa meskipun berbagai upaya telah dilakukan namun umumnya taraf hidup nelayan pesisir berupa peningkatan kesejahteraan yang diharapkan masih sulit terwujud. Hal ini disebabkan kesulitan yang dialami nelayan pesisir untuk memperoleh modal usaha dari pemerintah sehingga pola hidup mereka sangat tergantung pada pola interaksi patron-klien antara nelayan dengan para tengkulak selaku pemilik modal dan aset perikanan (Nugroho et al., 2011) juga menyatakan kemiskinan masyarakat pesisir berakar pada keterbatasan akses permodalan dan kultur kewirausahaan yang rendah. Keterbatasan akses permodalan membuat nelayan terjerat oleh para tengkulak, atau punggawa, yang kenyataannya tidak banyak menolong untuk meningkatkan kesejahteraannya malah cenderung menjeratnya dalam lilitan utang yang tidak pernah dapat dilunasi sedangkan kultur kewirausahaannya masih bercorak manajemen keluarga dengan orientasi sekedar memenuhi kebutuhan hidup sehari-hari (subsistence). Nelayan memiliki tipologi modal sosial terikat yang perlu kebijakan dalam rangka meningkatkan modal sosial di masyarakat nelayan itu sendiri (Pontoh, 2010). Kebijakan yang dimaksud adalah perbaikan struktur sosial yang terkait dengan kehidupan ekonomi masyarakat nelayan. Melalui kebijakan ini diharapkan hubungan antar anggota dalam satu kelompok terfokus pada masalah ekonomis sehingga hubungan antar kelompok akan terjalin kuat. Model pemberdayaan ekonomi masyarakat nelayan yang paling sesuai dengan karakter dan kondisi masyarakat Madura adalah pemberdayaan yang dilakukan oleh pangamba' (Saidi, 2014). Pangamba' terdiri atas pangamba' perseorangan dan pangamba' kelompok. Pangamba' perseorangan adalah model pemberdayaan ekonomi yang paling sesuai dengan masyarakat nelayan. Dalam melakukan pemberdayaan, pangamba' tidak merencanakan secara sistematis tetapi berjalan apa adanya. Pangamba' perseorangan memberikan sejumlah kompensasi kepada nelayan penggarap yang menjadi mitra kerjanya yang oleh sebagian keluarga nelayan dijadikan modal dalam membuka usaha. Dari beberapa kasus yang ada, keluarga 
nelayan yang membuka modal usaha dari uang kompensasi pangamba' perseorangan mampu meningkatkan ekonomi keluarga. Sementara pemberdayaan yang dilakukan Pemerintah melalui berbagai macam program pemberdayaan belum mencerminkan hasil untuk penguatan ekonomi masyarakat nelayan. Bantuan pemerintah yang diberikan secara langsung oleh pemerintah kepada nelayan pesisir pun tidak efektif untuk meningkatkan taraf hidup nelayan penerima bantuan. Hasil program pemberdayaan selama ini hanya dirasakan sesaat ketika bantuan diberikan karena ketidakjelasan program maka bantuan finansial yang seharusnya digunakan untuk pengembangan usaha dalam jangka panjang pada akhirnya hanya digunakan untuk menutupi kebutuhan hidup seharihari (Sartika, 2011). Hal ini terjadi pada program pemberdayaan bantuan usaha perikanan dan dana bergulir. Secara nyata belum terasa dampak signifikan yang dapat meningkatkan kesejahteraan nelayan di Kecamatan Pangandaran dalam jangka panjang. Perlu dicari alternatif kebijakan yang benar-benar terkonsep dan diduga dapat meningkatkan kesejahteraan nelayan dalam jangka panjang sehingga akar kemiskinan bisa segera diberantas dengan tuntas. Dalam menghadapi kesulitan hidup, para nelayan melakukan diversifikasi pekerjaan seperti pola nafkah ganda. Rendahnya akses terhadap modal terutama modal finansial merupakan penyebab kemiskinan (Widodo, 2011). Akses yang terbatas terhadap modal finansial menyebabkan nelayan tidak mampu mengakses modal fisik berupa teknologi penangkapan yang lebih modern. Kondisi ini semakin diperparah dengan adanya konflik perebutan sumber daya dengan nelayan dari daerah lain. Strategi nafkah yang dilakukan oleh rumah tangga nelayan miskin terdiri atas strategi ekonomi dan strategi sosial. Strategi ekonomi dilakukan dengan cara melakukan pola nafkah ganda, pemanfaatan tenaga kerja rumah tangga, dan migrasi. Sedangkan strategi sosial dilakukan dengan memanfaatkan ikatan kekerabatan yang ada. Lembaga kesejahteraan tradisional juga mempunyai peran yang penting bagi rumah tangga miskin dalam memenuhi kebutuhan hidupnya. Modal sosial mempunyai peran yang cukup penting dalam strategi nafkah rumah tangga miskin dan dapat menjadi salah satu pokok perhatian dalam upaya penyusunan strategi nafkah berkelanjutan. Pendekatan yang paling sesuai dengan kondisi masyarakat nelayan adalah model pendekatan dialogis (Kamuli, 2012). Selain pendekatan dialogis, pemerintah harus membantu nelayan pesisir untuk meningkatkan kemampuan individu. Nelayan harus memiliki kemampuan dalam manajemen bantuan langsung (berupa bantuan fisik, teknis, dan uang) (Razali, 2004). Persoalan lainnya adalah bagaimana menumbuhkan organisasiorganisasi desa yang baik, produktif ,dan mampu bersaing, sehingga dapat bernegosiasi dan tawar menawar dengan pemerintah maupun agen-agen pembangunan untuk meningkatkan rasa saling percaya pada kelompok atau komunitas yang berakar pada norma sosial, adat istiadat, dan etika sosial yang dimiliki setiap kelompok atau komunitas secara bersama-sama. Kemampuan manajerial nelayan pesisir terlihat dari rendahnya pengembalian dana pinjaman seperti yang diungkapkan dalam penelitian Asmara (2007) menyatakan faktor-faktor yang berpengaruh terhadap besarnya tunggakan KMP adalah variabel jumlah pinjaman dan tingkat pendidikan. Peran LEPP-M3 dalam memperluas akses pasar relatif belum terlalu dirasakan 
oleh KMP. Organisasi sosial dan ekonomi dapat bermanfaat dalam peningkatan taraf hidup dan kualitas hidup masyarakat di desa (Wasak, 2012). Organisasi sosial yang ada di desa ini adalah organisasi rukun duka, perkumpulan muda-mudi, ibu-ibu Majelis Taklim, gotongroyong pada acara pernikahan, dan Komite Sekolah. Organisasi sosial 'Rukun Duka' telah lama terbentuk secara turun temurun dan sampai saat ini tetap bertahan dan berjalan dengan baik. Organisasi ini diatur secara resmi oleh pemerintah desa dimana setiap anggota diwajibkan membayar uang Rp 3.000 serta membawa beras satu liter ketika ada salah satu anggota yang meninggal dunia. Semua warga desa ini yang sudah menikah otomatis menjadi anggota organisasi sosial rukun duka ini. Adapun komunikasi pembangunan turut berperan dalam pemberdayaan masyarakat nelayan pesisir seperti yang dikemukakan Amanah (2010) menyatakan peran penting komunikasi pembangunan dalam pemberdayaan masyarakat pesisir adalah menjembatani kesenjangan yang terjadi antara kondisi masyarakat saat ini dengan kondisi yang ingin dicapai melalui proses-proses komunikasi yang partisipatif, dialogis, dan memotivasi. Kesuksesan nelayan dalam meningkatkan taraf hidup mereka melalui kelompok nelayan berpadu dengan kearifan lokal di daerah (Harini, 2012). Faktor ekonomi, prestise, dan keinginan untuk melihat dunia luar merupakan dasar keputusan menjadi nelayan longlenan (Harini, 2012). Jaringan sosial yang digunakan nelayan longlenan adalah dengan berbagi informasi dan keberadaan broker. Dampak adanya nelayan longlenan adalah perubahan ekonomi, penghargaan sosial yang lebih tinggi terhadap profesi longlenan, perubahan gaya hidup, perubahan relasi dan nilai dalam keluarga, serta tranformasi profesi.

\section{PEMBAHASAN}

Dari literasi jurnal diatas maka terdapat sejumlah faktor yang merupakan ciri khas masyarakat nelayan pesisir dalam kehidupan seharihari. Terdapat empat ciri-ciri lingkungan sosial budaya nelayan pesisir, yaitu (Kusnadi, 2004):

\section{Sistem gender}

Dalam masyarakat nelayan implementasi dari sistem gender adalah pembagian tugas dan beban kerja antara laki-laki dan perempuan atau dalam rumah tangga nelayan pesisir tugas yang berbeda dibebankan pada suami dan istri. Adapun dari hasil penelitian, tugas nelayan laki-laki atau suami pada "ranah laut" sedangkan perempuan atau istri pada "ranah daratan". Pekerjaan-pekerjaan di laut, seperti melakukan kegiatan penangkapan, menjadi ranah laki-laki karena karakteristik pekerjaan ini membutuhkan kemampuan fisik yang kuat, kecepatan bertindak, dan berisiko tinggi. Dengan kemampuan fisik yang berbeda, kaum perempuan menangani pekerjaan-pekerjaan di darat, seperti mengurus tanggung jawab domestik, serta aktivitas sosial-budaya dan ekonomi. Keterlibatan perempuan nelayan dalam mencari nafkah tidak diimbangi dengan kemampuan dan ketrampilan yang dimiliki sehingga perlu adanya pemberdayaan untuk masyarakat nelayan terutama untuk perempuan nelayan agar mereka dapat meningkatkan kualitas hidup mereka (Masitho et al., 2013). Kaum perempuan memiliki cukup banyak waktu untuk menyelesaikan tangung jawab pekerjaan tersebut. Diversifikasi pekerjaan yang 
dilakukan oleh masyarakat nelayan sebagai salah satu strategi untuk mempertahankan kelangsungan hidup (Haryono, 2005). Oleh sebab itu, sebagian besar aktivitas perekonomian di kawasan pesisir melibatkan kaum perempuan dan sistem pembagian kerja tersebut telah menempatkan kaum perempuan sebagai "penguasa aktivitas ekonomi pesisir". Dampak dari sistem pembagian kerja ini adalah kaum perempuan mendominasi dalam urusan ekonomi bahkan perempuan menjadi pengambil keputusan penting dalam rumah tangga.

\section{Relasi Patron - Klien}

Pada umumnya, relasi patron-klien terjadi secara intensif pada suatu masyarakat yang menghadapi persoalan sosial dan kelangkaan sumber daya ekonomi yang kompleks. Biasanya tidak ada ikatan kerjasama secara resmi antara patron dan klien tersebut tapi keduanya memiliki kepentingan yang sama. Peran patron biasanya dimainkan oleh pemilik modal besar yang dikenal dengan sebutan juragan, bos, atau tauke seperti nelayan pemilik kapal, agen pengumpul ikan, pemilik modal besar yang dengan mudah dapat memberikan bantuan pada nelayan dan keluarganya tanpa syarat dan jaminan apapun sehingga kerjasama ini menjadi langgeng. Peranan klien tentu saja dimainkan oleh nelayan buruh yang tidak memiliki modal atau akses modal untuk menjalankan kegiatan melaut.

Keadaan ekonomi yang buruk sehingga para nelayan buruh seringkali terpaksa meminjam uang dan barang-barang kebutuhan hidup sehari-hari dari para juragan atau tauke dengan konsekuensinya para nelayan buruh tersebut menjadi terikat dengan juragan atau pedagang. Hubungan patron-klien tidak hanya sebatas hubungan bisnis semata tetapi hubungan terjalin hingga menyentuh masalah pribadi rumah tangga nelayan seperti: memberi pinjaman untuk pernikahan anak, membantu melunasi hutanghutang terdahulu, membayar kebutuhan sekolah, dan lain sebagainya. Hubungan ini kemudian melahirkan 'hutang budi' pada nelayan selaku klien sehingga menimbulkan keterikatan berupa keharusan menjual produk hasil tangkapan kepada patron (juragan atau tauke). Tentu saja bentuk kerjasama diatas membuat nasib nelayan buruh sangat mudah didominasi dan dieksploitasi oleh patron. Hal ini berdampak pada peningkatan ekonomi keluarga nelayan buruh

\section{Eksploitasi Sumber Daya Alam}

Dalam konteks hubungan eksploitasi sumber daya perikanan, masyarakat nelayan kita memerankan empat perilaku sebagai berikut: (1) mengeksploitasi terus-menerus sumber daya perikanan tanpa memahami batas-batasnya; (2) mengeksploitasi sumber daya perikanan, disertai dengan merusak ekosistem pesisir dan laut, seperti menebangi hutan bakau serta mengambil terumbu karang dan pasir laut; (3) mengeksploitasi sumber daya perikanan dengan cara-cara yang merusak (destructive fishing), seperti kelompok nelayan yang melakukan pemboman ikan, melarutkan potasium sianida, dan mengoperasikan jaring yang merusak lingkungan, seperti trawl atau minitrawl; serta (4) mengeksploitasi sumber daya perikanan dipadukan dengan tindakan konservasi, seperti nelayan-nelayan yang melakukan penangkapan disertai dengan kebijakan pelestarian terumbu karang, hutan bakau, dan 
mengoperasikan jaring yang ramah lingkungan. Perilaku eksploitatif diatas berimplikasi luas terhadap kelangkaan sumberdaya perikanan dan kemiskinan nelayan. Di samping itu, kompetisi antar nelayan buruh memperebutkan sumber daya perikanan terus meningkat sehingga berpotensi menimbulkan konflik khususnya di wilayah perairan yang menghadapi kondisi penangkapan berlebihan (overfishing).

\section{Kepemimpinan Sosial}

Masyarakat pesisir pada umumnya telah menjadi bagian masyarakat yang pluralistik tetapi masih memiliki jiwa kebersamaan yang kuat. Hal ini berarti struktur masyarakat pesisir merupakan gabungan antara masyarakat perkotaan dan pedesaan. Struktur masyarakat pesisir yang sangat plural sehingga membentuk sistem dan nilai budaya yang merupakan akulturasi budaya dari masing-masing komponen yang membentuk struktur masyarakatnya. Hidup berkelompok bukan hanya budaya yang dianut nelayan pesisir secara turun temurun tetapi juga memiliki alasan ideologis yang bertujuan untuk saling membantu dan peduli di masa sulit. Di dalam kelompok nelayan terdapat pimpinan non formil yang dikenal dengan opinion leader yang dipercaya oleh anggota kelompoknya untuk mengambil putusan guna menjaga kehidupan yang selaras atau kebersamaan.

\section{Kepemimpinan pada Kelompok Nelayan Pesisir \\ Bila dicermati pergeseran} paradigma pembangunan terkait dengan era keterbukaan informasi berbasis kepentingan masyarakat yang bertujuan untuk mencapai kesejahteraan masyarakat maka saat ini memasuki paradigma konvergensi (keberagaman) atau dalam komunikasi dikenal dengan istilah paradigma partisipatif. Komunikasi konvergensi adalah komunikasi yang sifatnya dialogis dimana individu membagi informasi dengan individu lain dalam keadaan setara guna mencapai konvergensi atau saling pemahaman bersama dan kesepakatan bersama untuk mencapai tujuan komunikasi yang melibatkan masyarakat secara langsung (Roger \& Kincaid, 1981). Sosiolog J.D Halloran menyatakan bahwa komunikasi terjadi di dalam suatu matriks sosial dimana situasi tempat komunikasi bermula, berkembang, dan berlangsung. Ini berarti para komunikator massa sebagai orang yang menduduki posisi penting yang peka dalam jaringan sosial menanggapi berbagai tekanan dengan menolak dan memilih informasi yang semuanya terjadi di dalam sistem sosial yang bersangkutan (Nimmo, 1989). Komunikator pada kelompok nelayan dapat disebut juga opinion leader yang melakukan kepemimpinan pada kelompoknya.

Peranan opinion leader dalam kelompok nelayan pesisir sangat besar walaupun bersifat informal karena mereka memainkan peranan sebagai komunikator politik yang menjadi peran sosial yang utama, terutama dalam proses menciptakan opini publik (Halloran dalam Nimmo, 1989). Para opinion leader ini menciptakan opini publik karena mereka berhasil membuat beberapa gagasan, mula-mula ditolak tapi lama kelamaan diterima oleh khalayak. Semua pembicaraan terkait dengan isu publik untuk mencapai kepentingan elit (Mc Naire, 2011). Komunikasi meliputi politik, misalnya orang mengamati konflik dan menyelesaikan perselisihan melalui komunikasi. Penyelesaian itu adalah hal-hal yang diamati, diinterpretasikan dan dipertukarkan melalui komunikasi. Transaksi tersebut adalah transaksi 
politik sehingga muncul makna perselisihan sosial dan dalam penyelesaiannya tercipta konflik-konflik baru (Nimmo, 1989). Opinion leader di dalam kelompok nelayan juga berfungsi sebagai pemimpin yang berpolitik. Definisi pemimpin kelompok (Nimmo, 1989) bahwa 1) pemimpin kelompok merupakan seperangkat fungsi kelompok yang harus terjadi di dalam setiap kelompok jika kelompok itu harus berperilaku secara efektif untuk memenuhi kebutuhan-kebutuhan para anggotanya, 2) pemimpin kelompok adalah proses ketika seorang individu secara konsisten menimbulkan lebih banyak pengaruh daripada orang lain dalam melaksanakan fungsi-fungsi kelompok, 3) pemimpin kelompok adalah anggota masyarakat yang menduduki posisi yang membuatnya bisa menyampaikan opini tentang masalah-masalah kepada orang-orang, 4) pemimpin adalah orang tertentu di dalam kelompok yang bertugas mengarahkan dan mengkoordinasi kegiatan kelompok yang bertalian dengan tugas, 5) kepemimpinan adalah suatu proses kelompok. Ralph.M.Stogdill merangkum definisi kepemimpinan dalam kelompok melibatkan proses kelompok, pengaruh kepribadian, seni meminta kerelaan, penggunaan pengaruh, persuasi, pencapaian tujuan, interaksi, peranperan yang diperbedakan, dan pembentukan struktur dalam kelompokkelompok (Nimmo, 1989). Bila ditinjau dari kehidupan sosial budaya masyarakat nelayan pesisir, ada banyak hal yang menyebabkan mereka sulit bangkit dari kemiskinan bahkan kemiskinan seolah-olah menjadi trademark nelayan pesisir (Razali, 2004).

Salah satu strategi yang dapat ditempuh adalah dengan memberdayakan kelompok-kelompok nelayan melalui pemimpin kelompok yang memiliki kemampuan opinion leader. Salah satu faktor yang harus dikuatkan adalah meningkatkan partisipasi politik masyarakat lokal (nelayan) yang dilandasi adanya keswadayaan ekonomi dan politik (self reliance) (Razali, 2004). Nelayan pesisir sebagai aktor pembangunan di lautan haruslah didengarkan pendapatnya sehingga bentuk komunikasi partisipatif merupakan pilihan terbaik bagi pemerintah atau lembaga-lembaga sosial lainya yang ingin memberikan bantuan ekonomi guna meningkatkan pemberdayaan ekonomi masyarakat nelayan pesisir. Karakteristik komunikasi partisipatif yang menjadi dasar utama dalam implementasi (Mefalopulos, 2003), yaitu: pertukaran informasi secara horizontal antara masyarakat maupun top-down bottom-up; (b) terjadinya komunikasi dialogis antara stakeholder utama dalam pengambilan keputusan tentang masalah yang timbul dalam masyarakat serta mencari solusi masalahnya; (c) kedudukan komunikator dan komunikan sama artinya dalam proses komunikasi partisipatif masyarakat yaitu kadang sebagai komunikator dan komunikan, sebab dalam proses komunikasi terjadi sharing informasi untuk mendapatkan saling kesepahaman antara anggota kelompok masyarakat dan; (d) memiliki kekuasaan yang sama kepada seluruh stakeholder utama untuk menyampaikan aspirasi (kebutuhan sendiri), memiliki kedudukan yang sama dalam pengambilan keputusan.

Pengelolaan laut dan perikanan (pesisir) yang telah dilakukan negara belum sepenuhnya mampu melindungi laut dan perikanan (pesisir) dari eksploitasi manusia, baik itu dari pengusaha maupun dari masyarakat sendiri. Bersamaan dengan itu, partisipasi kelompok nelayan pesisir belum secara penuh terlibat dalam pengelolaan laut dan perikanan. Dengan 
perkataan lain, pengelolaan laut dan perikanan (pesisir) dengan perspektif produksi, efisiensi, sosial, ekonomi, lingkungan harus menjadi komitmen dan tujuan dari pengelolaan laut dan perikanan (pesisir). Artinya pengelolaan sumberdaya laut dan perikanan (pesisir) yang secara turun temurun dan berkelanjutan telah dipraktekkan dan dikembangkan oleh masyarakat nelayan pesisir harus digunakan untuk kesejahteraan mereka. Sebagian nilainilai perilaku sosial di atas merupakan modal sosial yang sangat berharga jika didayagunakan untuk membangun masyarakat nelayan pesisir. Demikian juga, syarat-syarat pemimpin dan kepemimpinan masyarakat pesisir memiliki relevansi yang baik untuk merekonstruksi kepemimpinan bangsa dan negara Indonesia. Penjelajahan terhadap nilai-nilai budaya kepesisiran ini tentu saja memiliki kontribusi yang sangat strategis untuk membangun masa depan bangsa yang berbasis pada potensi sumber daya kemaritiman nasional.

\section{KESIMPULAN}

Dari literasi jurnal diatas maka dapat disimpulkan beberapa hal yaitu :

1. Pembagian kerja nelayan pesisir berdasarkan gender sangat efektif untuk memenuhi kebutuhan keluarga terutama pada saat nelayan tidak pergi mencari ikan di laut,

2. Relasi patron-klien sulit untuk dihilangkan apabila nelayan tidak memiliki konsep diri yang kuat untuk berdaya dan mandiri,

3. Komunikasi kelompok nelayan dapat dilakukan dengan efektif apabila pemimpin kelompok sekaligus sebagai opinion leader mampu berkomunikasi dengan anggotanya dengan menggabungkan 'kearifan lokal' dan pengetahuan tentang pemberdayaan dan kemandirian untuk nelayan pesisir.

\section{DAFTAR PUSTAKA}

Amanah S. 2010. Peran Komunikasi Pembangunan dalam Pemberdayaan Masyarakat Pesisir. Jurnal Komunikasi Pembangunan. Vol 8 No.1.

Asmara A. 2007. Tingkat Pengembalian

Pinjaman Dana Ekonomi

Produktif Masyarakat dan Peran Lembaga Keuangan pada Program Pemberdayaan Ekonomi Masyarakat Pesisir di Kab.Indramayu. Jurnal Manajemen Agribisnis. Vol 4 No.1.

Fargomeli F. 2014. Interaksi Kelompok Nelayan dalam Meningkatkan Taraf Hidup di Desa Tewil Kec.Sangaji Kab.Maba

Halmahera Timur. Jurnal Acta Diurna. Vol 3 No.3.

Ginkel, Rob van. 2007. Coastal Cultures: An Anthropology of Fishing and Whaling Traditions. Apeldoorn: Het Spinhuis Publishers.

Harini ND. 2012. Dari Miyang ke Longlenan : Pengaruh Jaringan Sosial Pada Transformasi Masyarakat Nelayan. Jurnal Komunitas. Vol 4 No.2.

Haryono T. 2005. Strategi Kelangsungan Hidup Nelayan. Jurnal Berkala Ilmu Kependudukan. Vol 7 No.2.

Kamuli S. 2012. Dampak Implementasi Kebijakan Taksi Mina Bahari Pada Produktivitas Nelayan Tradisional. Jurnal Ilmu Administrasi Negara. Vol 12 No.2.

Kusnadi. 2004. Mengatasi Kemiskinan Nelayan Jawa Timur, Pendekatan Terintegrasi. Yokyakarta : Pembaharuan 
Masitho BD, Lestari P, Herna MS. 2013. Kehidupan Sosial Ekonomi Perempuan dalam Masyarakat Nelayan di Desa Panjang Baru Kecamatan Pekalongan Utara. Unnes Civic Education Journal. Vol 2 No.2.

McNair, B. 2011. An Introduction To Political Communication Fifth Edition. Routledge. New York.

Mefalopulos P. 2003. Theory of Practice of Participatory Communication : The Case of the FAO Project "Communication for Development in Southern Africa. [Desertasi]. The University of Texas at Austin.

Nimmo D. 1989. Komunikasi Politik. Bandung : Remadja Karya

Nugroho AS, Monintja DR, Hardjo H. 2011. Analisis Aplikasi Model Lembaga Keuangan Mikro dalam Program Pemberdayaan Ekonomi Masyarakat Pesisir Di Kabupaten Cirebon.

Pontoh O. 2010. Identifikasi dan Analisis Modal Sosial dalam Rangka Pemberdayaan Masy.Nelayan Ds Gangga Dua
Kabupaten Minahasa Utara. Jurnal Perikanan dan Kelautan Tropis. Vol 6 No.3.

Razali I. 2004. Strategi Pemberdayaan Masyarakat Pesisir Laut. Jurnal Pemberdayaan Komunitas. Vol 3 No. 2.

Roger EM, Kincaid DL. 1981. Communication Network Towards New Paradigm for Research. New York. A Division of Macmillian Publishing Co.Inc.

Saidi M. 2014. Model Pemberdayaan Ekonomi Masyarakat Nelayan. Jurnal Ilmu Ekonomi dan Manajemen. Vol 10 No.1.

Sartika I. 2011. Evaluasi Kebijakan Pemberdayaan Nelayan. Jurnal Ilmu Administrasi Negara. Vol 11 No.2.

Wasak M. 2012. Keadaan Sosial Ekonomi Masyarakat Nelayan di Desa Kinabuhutan Kec.Likupang Barat Kab.Minahasa Utara Sulawesi Utara. Pacific Journal. Vol 1 No.7.

Widodo S. 2011. Strategi Rumah Tangga Miskin di Daerah Pesisir. Jurnal Makara Sosial Humaniora. Vol 15 No.1. 